\title{
КОЛЕГІАЛЬНІ ОРГАНИ В ОРГАНІЗАЦІЙНО-УПРАВЛІНСЬКІЙ СТРУКТУРІ УНІВЕРСИТЕТІВ УКРАЇНИ ХІХ СТОЛІТТЯ
}

\author{
Л. Д. Зеленська
}

Зеленська Л. Д. Колегіальні органи в організаційно-управлінській структурі університетів України XIX століття. У статті визначено місце і роль учених рад як органів колегіального самоврядування ворганізаційно-управлінській структурі університетів України XIX століття; обгрунтовано періодизацію їх діяльності в окреслений історичний період; охарактеризовано функції в контексті делегованої автономії.

Ключові слова: учена рада; університети України; управління; автономія; самоврядування; функції.

Зеленская Л. Д. Коллегиальные органы в организационно-управленческой структуре университетов Украины XIX века. В статье определены место и роль учених советов как органов коллегиального самоуправления в организационно-управленческой структуре университетов Украины XIX века; обоснована периодизацию их деятельности в исследуемый период; дана характеристика функций в контексте делегированной автономии.

Ключевые слова: ученый совет; университеты Украины; управление; автономия; самоуправление; функции.

Zelenska L. D. Collegial Bodies in the Organizational and Management Structure of Universities in Ukraine of the $\mathbf{1 9}^{\text {th }}$ Century. The place and the role of scientific councils as collegial self-governing bodies in the management and organizational structure of universities in Ukraine in the $19^{\text {th }}$ century have been determined. The periodization of activities of scientific councils in the analyzed period has been substantiated. The functions of scientific councils in the context of delegated autonomy have been characterized. tions.

Keywords: scientific council; universities of Ukraine; government; autonomy; self-government; func-

Потреба децентралізації управління вищою школою України як передумови інноваційного шляху іiі розвитку, перенесення центру ваги у прийнятті рішень на рівень вищого навчального закладу зумовлюють необхідність посилення ролі колегіальних органів, зокрема вчених рад, які мають стати провідниками інституційної, академічної, фінансової автономії вищої школи, дієвим засобом подолання суб'єктивізму в процесі прийняття управлінських рішень.

У зв'язку з цим актуалізується потреба неупередженого аналізу досвіду минулого, який дасть можливість для об'єктивного висвітлення генезису, змісту, напрямів діяльності вчених рад, урахування особливостей їх функціонування на різних етапах розвитку університетської освіти в Україні.

Найбільший науковий інтерес у вказаній площині викликає період XIX століття, що увійшов в історію Російської держави як «століття реформ» ${ }^{1}$. Він особливо виправданий на тлі тих стратегічних завдань реформування вищої школи в Україні, які пов'язані з утвердженням академічних свобод і цінностей, оскільки становлення університетської освіти, що відбувалося на українських землях Російської імперії в контексті соціально-економічних і політичних зрушень XIX століття, демонструвало різні підходи до розв'язання проблеми автономії вищої школи, забезпечення іiї функціонування на засадах колегіального самоврядування.

Історіографічний пошук засвідчив, що, не дивлячись на грунтовну розробку проблеми генезису університетів на теренах Російської імперії упродовж XIX століття, питання місця і ролі вчених рад в організаційно-управлінській структурі університетів України (Харківського, Київського, Новоросійського) не стали предметом окремого наукового пошуку. У дослідженні під час розробки вихідних положень окресленої проблеми ми спиралися на узагальнюючі праці А. Георгієвського ${ }^{2}$, М. Гілярова-Платонова ${ }^{3}$, О. Головніна ${ }^{4}$, С. Рождественського ${ }^{5}$, в яких діяльність учених рад розглядалася через призму урядової політики 
Російської імперії в галузі вищої освіти, що віддзеркалювалася, передусім, в університетських статутах, де на законодавчому рівні закріплювалися права й обов'язки загальноуніверситетських колегіальних органів.

Окрему групу дореволюційних джерел складають публіцистичні праці ліберально налаштованих авторів (В. Воробйов ${ }^{6}$, В. Іконников ${ }^{7}$, Б. Глінський ${ }^{8}$, К. Кавелін ${ }^{9}$, Д. Каченовський $^{10}$, М. Пирогов ${ }^{11}$, I. Соловйов $\left.{ }^{12}\right)$, які характеризували зміст університетських реформ XIX століття під кутом зору західноєвропейської університетської традиції й високо оцінювали роль учених рад в організаційно-управлінській структурі університетів Російської імперії.

Серед дореволюційних видань 3 питань університетської освіти на особливу увагу заслуговують узагальнюючі праці Д. Багалія ${ }^{13}$, В. Бузескула ${ }^{14}$, М. Владимирського-Будано$\mathrm{Ba}^{15}$, А. Маркевича ${ }^{16}$, М. Сумцова ${ }^{17}$, В. Шульгіна ${ }^{18}$, Ф. Фортинського ${ }^{19}$, в яких представлено досвід діяльності вчених рад Харківського, Київського та Новоросійського університетів упродовж досліджуваного періоду відповідно до чинних статутів.

Починаючи з 20-х і до початку 70-х років XX століття, питання колегіальності як принципу управління вищою школою в радянській історіографії не досліджувалося, оскільки вчені ради були оголошені радянським керівництвом «потугами віджитого феодалізму й буржуазного парламентаризму». Лише наприкінці 70-х - на початку 80 -х років XX століття вийшли друком монографії П. Зайончковського ${ }^{20}$, Р. Еймонтової ${ }^{21}$, А. Іванова ${ }^{22}$, В. Лейкіної-Свірської23, Г. Щетиніної ${ }^{24}$, в яких у контексті аналізу проблеми автономії університетів XIX століття побіжно аналізувалися повноваження вчених рад.

У останні десятиліття інтерес дослідників до питань організаційного устрою університетів України значно підвищився. 3'явилася низка наукових розробок, у яких автори в контексті висвітлення генезису університетської освіти на українських землях російської імперії частково торкалися й різноманітних аспектів діяльності вчених рад (склад, перерозподіл повноважень відповідно до чинних статутів, роль у розв'язанні студентських питань, заміщенні кафедр, присудженні наукових ступенів тощо). Характерною їх особливістю $є$ прагнення позбутися застарілих підходів в оцінці колегіальності як базового принципу управління вищою школою. Це переважно дисертації та монографії провідних учених з питань філософії освіти (Д. Дзвінчук, М. Зубрицька, В. Кремень, О. Кузь, О. Мещанінов, М. Поляков, Л. Семененко); історії становлення та розвитку вищої школи в Україні (А. Алексюк, Л. Ваховський, О. Глузман, Н. Дем’яненко, С. Золотухіна, Б. Свтух, I. Курляк, О. Любар, В. Майборода, О. Микитюк, Л. Прокопенко, О. Сухомлинська), а також дослідження науковців, що представляють історичну науку (К. Астахова, В. Іващенко, Б. Зайцев, Г. Косінова, Л. Посохова, С. Посохов, А. Таньшина, С. Черняк (Україна); А. Андрєєв, Є. Вишленкова, В. Змєєв, К. Ільїна, Т. Костіна, Н. Ладижець, Л. Лаптєва, Є. Ляхович, Ф. Петров, А. Ревушкін, О. Феофанов, В. Чесноков (Росія).

Утім, до цього часу місце і роль учених рад в організаційно-управлінській структурі університетів України XIX століття як окрема наукова проблема комплексно й системно в обраних хронологічних межах не досліджувалася.

Як відомо, період кінця XVIII - початку XIX століття в історії українського, як й інших народів Російської держави, став добою кризи старого режиму (ancien regime) та переходу до нової, модерної епохи, що поступово охоплювала всі сфери соціального, економічного й культурного життя суспільства. За оцінкою В. Ключевського, народна освіта ніколи ще не входила так тісно в загальні перетворювальні плани уряду, як у цей період²5.

Першим кроком на шляху реформування освітньої сфери стало створення Міністерства народної освіти (1802р.), наступним - прийняття спеціального законодавчого акта про базові основи нової системи освіти Російської імперії - «Попередніх правил народної освіти», які в частині про університети мали доповнюватися університетськими статутами. Головні проблеми, що стояли перед їх укладачами, не обмежувалися виключно сферою освіти та науки, а торкалися фундаментальних засад усього соціально-політичного ладу. Важливо було утримати баланс між вітчизняною освітньо-культурною та західною традиціями. Від вирішення цього питання залежало принципове для Російської держави питання про те, чи стануть майбутні університети державними установами з підготовки нового покоління чиновницької бюрократії, чи анклавами громадянського суспільства, що діють на засадах колегіального самоврядування ${ }^{26}$. 
Найбільш складну проблему в розробці університетського устрою складало питання про шляхи реалізації розповсюдженого на Заході принципу університетської автономії, який входив у протиріччя з чинними нормами державного централізму. Це ставило владу перед вибором: запроваджувати систему управління університетами на зразок німецьких, зокрема Геттінгена, надаючи широку автономію колегіальним органам, чи наполягати на жорсткій підконтрольності університетів попечителю й міністру, успадковуючи «французьку» модель ${ }^{27}$.

Протягом XIX століття університети чотири рази - за кількістю правлінь імператорів - зазнавали реформ і контрреформ, які простежувалися в університетських статутах (1804 p., 1835 p., 1863 р., 1884 р.). Питання університетської автономії було для них одним iз кардинальних. Так, якщо на початку XIX століття університетська автономія сприймалася в ракурсі «свободи» від державного керівництва й контролю, то на межі XIX-XX століття, пройшовши низку перехідних етапів, вона вбачалася лише у «виборності посадових осіб з обов'язковою їх підлеглістю органам державної влади» ${ }^{28} .3$ огляду на це, трансформаційних змін зазнавали й підходи до реалізації в університетах як державних установах принципу колегіального самоврядування.

Вищезазначене вимагає встановлення етапів генезису загальноуніверситетських колегіальних органів - учених рад, діяльність яких була спрямована на реалізацію окресленого принципу. Ураховуючи той факт, що саме соціальні, політико-правові, економічні й ідеологічні процеси разом з педагогічними задають параметри освітньої політики й виступають фундаментом для встановлення періодизації, нами було визначено такі критерії для обгрунтування етапів: соціально-економічні й політичні зрушення досліджуваного періоду, які виступали об'єктивними чинниками проведення університетських реформ; особливості урядової політики в галузі вищої освіти, що були відображені в університетських статутах, постановах, розпорядженнях, циркулярах Міністерства народної освіти й визначали ступінь реалізації принципу автономії й колегіального самоврядування; спектр делегованих ученим радам функцій, що визначали напрями їх діяльності; особливості формування особового складу вчених рад.

Перший етап (1804-1834 pp.) визначено як етап офіційного визнання й законодавчого оформлення діяльності вчених рад. У першій чверті XIX століття університети Російської імперії працювали за статутом 1804 року, що акумулював кращі досягнення тогочасної просвітницької педагогічної думки на Заході й базувався переважно на німецькій системі університетської автономії, втіленій у Геттінгенському університеті ${ }^{29}$. Саме в статуті 1804 року були закладені основи університетської автономії, яка передбачала перетворення університетів у самостійні науково-навчальні центри. Це вимагало, по-перше, введення системи колегіального самоврядування; по-друге, здійснення виборності керівного складу (ректора, проректора, деканів); по-третє, реалізації принципу самопоповнення викладацького складу шляхом обрання претендентів радою професорів без узгодження їхніх кандидатур з бюрократичними інстанціями; по-четверте, надання свободи наукових досліджень й викладання; по-п'яте, захисту навчального процесу від некомпетентного втручання представників урядової бюрократії ${ }^{30}$. Зважаючи на це, діяльність колегіального представницького органу університетського самоврядування - вченої ради мала вибудовуватися на підставі запозичених на Заході форм та способів взаємодії університетів з урядовими структурами.

У цілому ідея запровадження колегіального самоврядування в університетах Російської імперії ще від початку роботи над розробкою проекту статуту сприймалася неоднозначно. Так, В. Каразін, укладаючи «Предначертание» (проект статуту) передбачав зосередити функції управління університетом у руках директора. Така практика вже мала місце 3 часів заснування Московського університету (1755 р.). 3 приводу такого підходу до облаштування організаційно-управлінської структури університетів заслуговує на увагу думка професора Дерптського університету Паротта, який у листі до В. Каразіна зазначав: «Идея освободить профессоров от тяготи университетского управления останется, я думаю, благочестивым пожеланием, но едва ли оно примется. Ваш директор не из профессоров сделается, по самой природе вещей, вечным директором, и хорошо еще будет, если место это не сделается всегдашним наследием старих кляч, которых некуда девать. Никто не имеет такого отвращения от административных занятий, как я; но мне 
все-таки кажется, что нельзя иначе сохранить необходимую для университетов свободу действий, как вручив внутреннее их управление сословию профессоров. Вы, я уверен, не легкомысленно решились на такое важное нововведение и остается только желать, чтобы вам удалось согласить свободу университета с невмешательством преподавателей в его управление: вы решили бы этим задачу, над которою трудяться столько веков» ${ }^{31}$.

Однак, в офіційно затверджених статутах університетів Російської імперії, зокрема Статуті Імператорського Харківського університету (1804р.), відкритого на українських землях, знайшла відображення саме колегіальна форма управління, а Олександр I власноручно викреслив із поданих на розгляд проектів усе, що «могло б обмежити академічні свободи університетської корпорації» ${ }^{32}$.

Ідею колегіального самоврядування на практиці втілювала вчена рада, що формувалася 3 ординарних та заслужених професорів під головуванням ректора. Ад’юнкти мали право бути присутніми на засіданнях ради, але наділялися правом голосу тільки у разі обговорення питань організації навчального процесу. Склад ради вимагав затвердження міністра ${ }^{33}$. Так, згідно 3 даними Д. Багалія, до складу ради Харківського університету у 1805 р. входило 9 ординарних професорів і 9 ад’юнктів, у 1807 р. - 11 ординарних професорів, 1 екстраординарний і 7 ад'юнктів, у 1811 р. - 15 ординарних, 4 екстраординарних i 3 ад'юнкти ${ }^{34}$. На ректора покладалися обов'язки щомісячного скликання ради й головування на їі засіданнях.

Згідно зі статутом Харківського університету, рада визнавалася «вищою інстанцією» в організаційно-управлінській структурі університету. Відповідно, на неї покладалося виконання низки функцій. Зокрема, статут 1804 року закріплював за радою навчальну, наукову, судово-поліцейську, фінансово-господарську та громадсько-просвітницьку функції, що свідчить про досить широкий спектр напрямів діяльності загальноуніверситетського колегіального органу. Означені функції реалізовувалися в процесі вирішення поточних справ, а також таких, що не вимагали регулярного обговорення й ставилися на порядок денний за необхідності. Так, до поточних справ, які підлягали розгляду на засіданнях ученої ради належали: обрання професорів, почесних членів, ад'юнктів, а також затвердження на посадах викладачів університету, гімназій, повітових училищ, які «мали до цього певні здібності»; обговорення способів удосконалення викладання наук в університеті та училищах округу; затвердження порядку проходження навчальних курсів та визначення терміну для їх засвоєння; проведення щорічних іспитів студентів; обговорення пропозицій Міністерства народної освіти й ректора університету; ухвалення рішень за судовими справами, що надавалися для розгляду правлінням університету згідно поданих апеляцій ${ }^{35}$.

Окрім того, щомісяця мали призначатися особливі засідання вченої ради, де професори й почесні члени вели б дискусії з приводу наукових відкриттів, досліджень, творів. Тематику таких засідань міг пропонувати ректор або будь-хто з членів ради. Для заохочення наукових досліджень серед професорсько-викладацького складу рада щорічно пропонувала теми для конкурсних робіт із визначенням розміру винагороди за їх задовільне вирішення ${ }^{36}$.

Підкреслимо, що за статутом 1804 року Харківський університет виконував роль керівної освітньої установи в окрузі, що вимагало від нього широкої адміністративно-педагогічної діяльності. 3 огляду на це, компетенції вченої ради підлягали справи, які стосувалися організації діяльності початкових і середніх шкіл округу. Зокрема, на засіданнях ради Харківського університету обирався склад училищного комітету з 6 професорів під головуванням ректора, який здійснював керівництво навчальними закладами округу, призначалися візитатори, відбувалося заслуховування їхніх звітів, зарахування й звільненняз посади директорів і вчителів гімназій та училищ, доповідалися справи про відкриття навчальних закладів початкової та середньої ланки, будівництво для них приміщень тощо ${ }^{37}$.

Ученій раді як «найвищій інстанції» в організаційно-управлінській структурі університету були підзвітні інші адміністративні одиниці, зокрема зі справ навчальних - факультетські ради, зі справ поліцейських, фінансових, господарських і судових - правління. 3 огляду на це, один раз на рік рада була зобов'язана розглядати усі фінансові рахунки за підписами касира й бухгалтера, за якими доповідав ректор 38.

У перше десятиліття функціонування Харківського університету діяльність ученої ради характеризувалася активністю ії членів, змістовністю обговорення питань і доволі 
високою частотою проведення засідань. Наприклад, 1805 року їх було 42, 1806 - 40, 1807 48. Проте, за свідченням Д. Багалія, «члени ради не були ними обтяжені, оскільки кожного разу доводилося розглядати не якісь формальні, сухі, а живі, важливі й цікаві справи» ${ }^{39}$. Ix тематика була доволі широкою й багатогранною, а в рішеннях простежувалися «такт $\mathrm{i}$ виважене обгрунтування». На переконання дослідників ${ }^{40}$, цього вдавалося досягти завдяки «гуманності членів ради», наявності в них «прогресивних ідей і духу свободи», «любові до справи й освіти», навіть незважаючи на те, що половина членів ради, яку на початку діяльності Харківського університету складали професори-іноземці, не знала ні особливостей російського життя і побуту, ні російської мови.

Статут 1804 року наділяв раду відносною самостійністю і в стосунках з попечителем навчального округу. На це вказують положення про те, що лише через кожні півроку рада загальним рапортом мала доповідати попечителю про свою діяльність, а на кінець року надавати повний звіт. Тільки у разі виникнення надзвичайних обставин від неї вимагалося повідомляти про хід справи негайно ${ }^{41}$.

Проте відсутність фактичного досвіду реалізації самоврядування в умовах функціонування університету як державної установи, стійких традицій колегіального управління в Російській імперії часто призводили до безпрецедентного втручання як попечителя, так і міністра в роботу вченої ради Харківського університету, включаючи кадрові призначення й адміністративний тиск. Останній почав відчутно зростати вже після завершення війн з Наполеоном, коли в Європі встановився новий політичний та інтелектуальний клімат, пов'язаний з відмовою від ідеалів Просвітництва та повернення до традиційних релігійних канонів ${ }^{42}$. Так, перший конфлікт між ученою радою Харківського університету й Міністерством народної освіти було зафіксовано вже 1812 року, коли рада постановила звільнити з посади кількох учителів Курської гімназії за безлад у начальному закладі. Проте міністр народної освіти К. Розумовський скасував це розпорядження, направивши для ревізії стороннього чиновника. Спираючись на те, що згідно зі статутом 1804 року вчена рада $\epsilon$ кінцевою інстанцією з вирішення усіх шкільних справ округу, їі члени звернулися 3 протестом до міністра народної освіти. Комітет міністрів, розглянувши скаргу, виніс ухвалу оголосити членам ради догану з попередженням, якщо й надалі вони будуть виявляти подібну «неслухняність», зазнають покарання через суд. Рада Харківського університету, приголомшена таким вироком, не зуміла утриматися на висоті свого становища й звернулася до міністра 3 виправданням, у якому прохала про скасування принизливої догани. Останній, «зважаючи на каяття», догану публічну «з доброї ласки» змінив «на таємну» ${ }^{43}$.

Наступним кроком до посилення адміністративного впливу на діяльність учених рад, стало відкрите переслідування іноземних професорів. За свідченням Д. Багалія, іноземні професори «буквально розбіглися в різні сторони», налякані ксенофобією, зведеною в ранг державної політики. Якщо до 1811 року співвідношення російських та іноземних професорів у раді Харківського університету було постійним (приблизно один до двох), то 3 1822 року воно почало змінюватися на користь російських підданих, оскільки з 1815 року, згідно з розпорядженням Міністерства народної освіти, заміщення вакантних кафедр мало здійснюватися виключно російськими викладачами ${ }^{44}$. За оцінкою дослідників ${ }^{45}$, такі заходи не сприяли ні ліквідації постійного дефіциту кадрів в університеті, ні підвищенню його наукового потенціалу, оскільки підготовка учених не була поставлена на належний рівень. Це відразу позначилося на діяльності вченої ради Харківського університету, для якої став характерний вияв «апатії й байдужості» до вирішення університетських справ.

Починаючи з 20-х років XIX століття, суттєвих змін зазнали й стосунки вчених рад 3 попечителями навчальних округів, які влучно віддзеркалювали запроваджувану урядом політику «керованої демократії». Так, попечитель Харківського навчального округу Є. Карнєєв 1824 року подав на розгляд Училищного комітету проект реформування системи управління університетом, який мав на меті обмеження повноважень ученої ради. Зокрема, проектом передбачалося внесення змін до порядку обрання ректора й деканів. Є. Карнєєв доводив необхідність уведення процедури призначення ректора «вищим начальством» із «чиновників, які розуміються в науках і мають досвід служби», або з професорів, однак 3 обов'язковим звільненнямвід викладання. Посаду декана, на думку попечителя, мав обіймати спеціальний радник, який також призначався б на «розсуд начальства» ${ }^{46}$. Незважа- 
ючи на те, що цей проект не було схвалено, вже 1830 року набув чинності іменний указ, відповідно до якого запроваджувалася процедура «призначення ректора університету без установлення терміну перебування на цій посаді $\rangle^{47}$.

На початку 30-х років XIX століття Міністерство народної освіти, визнаючи «республіканський» устрій університетів таким, що не відповідає загальному державному курсу Росії, в основі якого лежить єдиноначальність управління й безпосередня залежність від верховної влади, вдалося до відкритої ревізії їх організаційно-управлінської структури. Так, на засіданні Комітету Міністрів, яке відбулося в квітні 1831 року, вперше було поставлено питання про необхідність відокремлення господарської, фінансової й усієї адміністративної частини управління університетом від навчальної із звільненням від цих обов'язків членів учених рад. Натомість функції університетської адміністрації й керівництва навчальним округом проектувалося передати попечителю ${ }^{48}$.

Апробація окресленої ідеї була здійснена вже під час уведення в дію статуту Університету Св. Володимира (1833р.), за зразком якого мав бути укладений загальний статут для всіх університетів Російської імперії. Статут Університету Св. Володимира був затверджений 25 грудня 1833 року як «тимчасовий» на 4 роки і мав набути юридичної сили лише по завершенні повного циклу університетського курсу. Тому навіть після офіційного визнання розглядався як «проект». У Всепідданійшій доповіді міністр народної освіти К. Лівен так сформулював «підтверджені досвідом покращення», що складали основу означеного статуту: «...університетське судочинство над своїми членами знищено; влада попечителя і вплив міністра визначені в чітких межах; господарська частина відокремлена від навчальної; внутрішня поліція передана особливому чиновнику, що не належить до університетської корпорації» ${ }^{49}$. Як висновок, документ містив таку тезу: «Загалом увесь процес управління внутрішнього пристосовано до вимог уряду про детальний і безпосередній нагляд за духом і перебігом вищих навчальних закладів ${ }^{50}$. Саме ця настанова стала базовою для нового Статуту Імператорських Російських університетів (1835 р.). Набувши статусу «Загального», він заклав підгрунтя для обмеження університетської автономії, провідних засад колегіального самоврядування, а відповідно звуження компетенції вчених рад.

Другий етап діяльності вчених рад університетів України охоплює період дії статуту 1835 року (1835-1862 рр.) й характеризується як етап перерозподілу їх повноважень на підставі реформування системи управління університетами Російської імперії. У статуті 1835 року знайшли відображення ті зміни в поглядах на університети як державні навчальні й наукові установи, межі університетського самоврядування, котрі давно визрівали в урядових колах. Статут позбавляв університети контролю за нижчою й середньою освітою в навчальному окрузі, права на власний суд, а також адміністративно-господарську діяльність. У зв'язку з цим функції вченої ради були значно звужені, що позначилося на обмеженні напрямів їх діяльності й зумовило перерозподіл повноважень між іншими управлінськими структурами. Зокрема, внаслідок передачі керівництва училищами округу в сферу компетенції попечителя, було ліквідовано училищні комітети, що перебували у підпорядкуванні вчених рад. Наразі вони частково втрачали свою просвітницько-виховну функцію. Згідно з положеннями статуту 1835 року ${ }^{51}$, тільки попечитель міг тепер ініціювати обговорення на засіданнях ради питання, що вимагали «навчальних міркувань», а саме: про удосконалення викладання наук у початковій і середній школі; запровадження додаткових курсів; використання навчальних посібників і керівництв тощо.

3 ліквідацією права університетів мати власний суд, учені ради втрачали судову функцію. Відтепер усі арештовані поліцією студенти, викладачі чи службовці університету в разі скоєння цивільних правопорушень підлягали владі ректора, карних - загальній юрисдикції за умови присутності на засіданнях суду спеціального представникавід університету ${ }^{52}$.

Внаслідок відокремлення адміністративної частини управління університетом від навчальної, посади університетського засідателя, синдика, секретаря ради й інспектора казеннокоштних студентів, які за статутом 1804 року покладалися на професорів і ад’юнктів й затверджувалися на засіданнях ради, мали обіймати військові або цивільні чиновники, що призначалися попечителем. Запровадження такого заходу мотивувалося тим, що керівництво господарською й адміністративною частинами університету відволікає професорів від їхнього прямого обов'язку - «розумової освіти студентів» ${ }^{53}$. 
До того ж, була значно послаблена залежність від ученої ради правління. Із виконавчого органу вченої ради з господарських, поліцейських, фінансових і судових справ воно перетворилосяна самостійний підрозділ з вирішення господарських питань ${ }^{54}$. Учена рада більше не отримувала від правління фінансових звітів і, не володіючи інформацією щодо власного бюджету, усувалася від розподілу матеріальних засобів ${ }^{55}$. Натомість усі позаштатні видатки у розмірі, що не перевищували 500 крб., стали вимагати погодження попечителя. Окрім того, останній набував права надавати дозвіл на використання одноразових видатків до 10000 крб., а також затверджувати контракти щодо надходжень коштів згідно укладеного кошторису.

Положення статуту 1835 року не передбачали й проведення окремих засідань ученої ради, що мали на меті розповсюдження наукових знань, а також визначення тем конкурсних наукових робіт. У цьому напрямі за радою закріплювалося лише право надавати дозвіл на відкриття наукових товариств ${ }^{56}$.

До того ж учені ради зазнали обмежень у формуванні професорсько-викладацького складу університету. Наразі, відповідно до ст. 80 статуту, не лише вчена рада, але й міністр набував права на власний розсуд призначати на вакантні кафедри професорів і ад’юнктів. Проте звільнення з означених посад все ж вимагало обов'язкового погодження з ученою радою ${ }^{57}$.

Отже, вилучивши із компетенції вчених рад судову, фінансову й адміністративно-господарську функції, статут 1835 року обмежив їх діяльність виключно справами навчального й наукового характеру. До поточних справ, які підлягали вирішенню на засіданнях ради, належали: обрання ректора (на 4 роки 3 подальшим затвердженням міністра), почесних членів і кореспондентів, а також професорів, ад'юнктів і лекторів університету; обговорення пропозицій щодо удосконалення викладання наук; розподіл навчальних курсів і визначення кількості годин на їх вивчення; розгляд подань факультетів на отримання кандидатами вчених звань; аналіз недоліків у виконанні професорами своїх обов'язків; загальне керівництво навчально-допоміжними установами; затвердження текстів наукових творів, перекладів, актових промов, які друкувалися за рахунок університету ${ }^{58}$.

Проте, всупереч низки обмежувальних заходів, що призвели до звуження сфери компетенції вчених рад, запровадження дрібної регламентації їх діяльності й підконтрольності попечителю, статут 1835 року мав більш сприятливий вплив на роботу вченої ради Харківського університету порівняно з останнім десятиліттям дії статуту 1804 року, коли в професорській колегії став переважати «дух апатії й байдужості». Це пояснюється, поперше, суттєвим оновленням складу вченої ради завдяки появі нових наукових сил, які створили в кінці $30-x$ - на початку 40 -х років «епоху пишного розквіту» викладацької діяльності професорів, відданих науці й університету. По-друге, звільненням професорів від важких і невдячних фінансово-господарських функцій, а також «громадського служіння», що цілком відповідало загальним настроям членів ученої ради, сприяло зосередженню їхньої уваги на питаннях удосконалення освітнього процесу й активізації науково-дослідної роботи.

Утім, взаємний компроміс між правлячим режимом і колегіальним самоврядуванням, який було закладено в положеннях статуту 1835 року, тривав порівняно недовго. Кінець 40-х - початок 50-х років XIX століття знову стали часом радикальних змін університетської політики російського уряду. Той же різкий поворот реакції, ксенофобії, антизахідництва, докорінний перегляд попередньої політики, насадження казенного патріотизму та православ'я, внаслідок яких право університетів на самоврядування значно обмежувалося. Так, під впливом подій 1848 року в Європі («весна народів») Міністерство народної освіти запровадило низку заходів, які мали на меті «вберегти російські університети від буревіїв, що хвилювали сусідні держави». Зокрема, вчені ради були позбавлені виборчого права, а міністр народної освіти дістав повноваження призначати ректорів і деканів на невизначений термін. Призупинялося й обрання проректорівдо особливого розпорядження.

За таких умов діяльність учених рад університетів України (Харківського та Київського) була практично паралізована ${ }^{59}$. Вони демонстрували «інертність» у ставленні до університетських справ, що зумовлювалося:

- відстороненням учених колегій від міркувань і ухвалення рішень 3 переважної більшості справ, пов'язаних із життям університету; 
- послабленням складу вчених рад. Після закриття професорського інституту в Дерпті, заборони запрошувати іноземних учених на вакантні кафедри, запровадження надзвичайно складної системи іспитів на здобуття наукових ступенів професійний рівень професорсько-викладацького складу значно знизився. Під час заміщення кафедр до уваги частіше бралися не наукові здобутки претендентів, а їхня «благонадійність»;

- низьким матеріальним забезпеченням професорів, що принижувало їхню гідність. 3 цього приводу Б. Глинський зазначав: «Вони все частіше зверталися до побічних занять, прагнучи покращити свій матеріальний стан, і більше дорожили цими побічними заняттями, ніж службою в університеті, а тим паче роботою в раді, яка забирала багато часу» ${ }^{60}$.

Лібералізація суспільного життя кінця 50-х років XIX століття, активізація студентського руху зумовили необхідність проведення докорінної університетської реформи. Уже з 1858 року розпочалася робота над виробленням нового проекту університетського статуту, а в грудні 1861 року комісією, очолюваною сенатором фон Брадке, була представлена його повна редакція. Ключовим питанням нового статуту стали положення щодо реалізації колегіального начала як принципу університетського управління, висловлені прихильниками університетської автономії й колегіального самоврядування під час громадського обговорення нового статуту (Д. Каченовський, М. Пирогов, С. Трубецькой, К. Тімірязєв, учені ради Харківського і Московського університетів та ін. $)^{61}$.

Означені чинники створили передумови докорінного реформування системи управляння університетами Російської імперіій заклали підгрунтя для нового етапу в роботі вчених рад університетів України. Він охоплює період дії статуту 1863 року (1863-1883 рр.) й характеризується як етап інтенсифікації діяльності вчених рад й поширення їх важелів впливу на всі сфери університетського життя.

Новий університетський статут, на підставі якого діяли п’ять університетів Російської імперії, зокрема Харківський та Київський, набув чинності 18 червня 1863 року. 1865 року відбулося офіційне відкриття Новоросійського університету в Одесі, на який також розповсюджувалася дія означеного статуту. Відповідно до нового засадничого документу, вчена рада набувала статусу «вищої інстанції» $з$ вирішення не тільки навчальних, але й господарських, судових, просвітницьких справ і підпорядковувала своїй владі інші управлінські структури (правління, університетський суд, інспекцію зі студентських справ). Проте рішення вченої ради вимагали або остаточного схвалення попечителя, або затвердження міністра. У такий спосіб влада залишала за собою право контролю за діяльністю органів університетського самоврядування й, зокрема, вченої ради.

Відповідно до положень статуту 1863 року, остаточному затвердженню ради підлягали справи, що стосувалися: розподілу предметів і порядку їх викладання на всіх факультетах; присудження медалей і призначення стипендій студентам; визначення премій за наукові дослідження, які пропонувалися вченим від імені університету; затвердження в учених ступенях та у званні дійсного студента; розподіл коштів, призначених згідно кошторису на розвиток навчально-допоміжних установ; залишення стипендіатів для приготування до професорського звання; рекомендації до друку наукових творів; заміщення вакантних кафедр на підставі оголошення конкурсу; затвердження щорічного кошторису, прибутків і видатків спеціальних коштів університету, а також ухвала постанов університетського суду ${ }^{62}$.

Погодження з попечителем вимагали рішення вченої ради щодо заходів для покращення наукової діяльності університету; обрання доцентів, лекторів, проректора або інспектоpa, почесних членів, суддів та кандидатів до університетського суду, а також допоміжного штатного персоналу університету. Окрім того, затвердженню попечителя підлягали укладені радою інструкція для проректора або інспектора та низка правил, а саме: про порядок стягнення, розподілу й використання коштів, сплачених студентами за навчання; прийом студентів до університету; допущення сторонніх осіб до слухання лекцій і встановлення за це відповідної плати; права й обов'язки студентів та визначення міри покарань за їх порушення; діловодство в університетському суді тощо.

Окрема група справ, що перебувала в компетенції вченої ради, через попечителя навчального округу передавалася на затвердження міністра, як-от: про обрання та звільнен- 
ня ректора, деканів, проректора або інспектора та професорів; розподіл факультетів на відділення, об'єднання й роз'єднання кафедр, заміну одних іншими; відрядження молодих науковців за кордон з метою підготовки до заміщення кафедр; правила щодо терміну й порядку проведення іспитів на присвоєння наукових ступенів і вчених звань, а також клопотання про заснування наукових товариств ${ }^{63}$.

Важливою рисою нового статуту стало набуття радами права на врахування регіональних особливостей у розв'язанні покладених на них справ, проте знову ж таки з дозволу попечителя. Підтвердженням може слугувати набуте радами Харківського і Київського університетів право самостійно складати низку правил, які регулювали внутрішній розпорядок в університеті («Про зарахування студентів до університету, перехід 3 одного факультету на інші та звільнення 3 університету» ${ }^{64}$, «Правила для студентів» ${ }^{65}$, «Загальні правила випробувань студентів» ${ }^{66}$ тощо).

До того ж, з метою запобігання свавілля в діяльності вчених рад, висувалася вимога звітності й гласності. У зв'язку з цим протоколи засідань учених рад із зазначенням думки меншості стали друкувати після ухвалення їх попечителем ${ }^{67}$. На кінець року рада складала повний звіт про свою діяльність і надавала його через попечителя міністру народної освіти.

Отже, якісні зміни в системі управління університетами, які відбулися на підставі поновлення статутом 1863 року автономії й права колегіального самоврядування, вплинули на те, що «вчена колегія стала живим органом університету, а його внутрішнє життя росло і розвивалося» ${ }^{68}$. Про те, як енергійно працювала вчена рада, наприклад Харківського університету, в перші роки введення в дію статуту 1863 року, красномовно свідчить той факт, що вже на першому її засіданні, яке відбулося після оприлюднення статуту (29 липня 1863 р.), було ухвалено: «Розпочати негайно, на підставі п. 42 складання: 1. Інструкції для проректора або інспектора. 2. Правил: а) про порядок збору, розподілу та використання коштів, які надходять за слухання лекцій; б) про прийом студентів до університету; в) про допуск сторонніх осіб до слухання лекцій та про стягнення за ці лекції плати; г) про обов'язки учнів та порядок в університеті; д) про покарання за порушення цих обов'язків» тощо ${ }^{6}$.

Високу, з нашого погляду, оцінку діяльності ради Харківського університету дав і попечитель навчального округу К. Фойгт. У своїй конфіденційній записці міністру він писав: «[Рада] дієво працює, члени їі радяться щотижня, іноді двічі на тиждень, і наради відбуваються спокійно й помірковано. Професори цілком усвідомлюють важливість покладеного на них обов'язку...» ${ }^{70}$.

Водночас зміна урядового курсу в бік обмеження права університетів на реалізацію колегіального самоврядування стає очевидною вже після замаху Д. Каракозова на Олександра II 1866 року. 3 цього часу відбувається відхід від ліберального напряму, який був продиктований завданнями ідеологічного впливу на суспільство, серед яких «знищення пропаганди шкідливих ідей, що суперечать державному благоустрою та громадській моралі, а також викорінення зла, що отруює молоде покоління» ${ }^{71}$. Жже 1872 року в Міністерстві народної освіти на порядок денний було поставлено питання про необхідність докорінного перегляду статуту 1863 року. Головне призначення нової реформи вбачалося в тому, щоб повернути університетам статус «державної установи», який вони, на думку реакціонерів, втратили в епоху 1860 -х років.

Питання про необхідність зміни внутрішньої організації університетів було остаточно вирішене 1874 року під час проведення особливої наради міністрів під головуванням графа Валуєва. На засіданні зазначалося, що вчені ради «не виявляють належного усвідомлення своїх стосунків з урядом і не володіють тим охоронним тактом, який необхідний для підтримки внутрішнього дисциплінарного устрою навчальних закладів; вони зневажають моральні способи впливу на учнів і нерідко сприяють свідомо й несвідомо втіленню в середовищі своїх слухачів хибних уявлень про їхнє становище в закладі і ставлення до влади» ${ }^{72}$. Таку позицію поділяли й критики колегіального начала в університетському управлінні (Д. Левшин, М. Любимов, М. Гиляров-Платонов, В. Катков та ін.), наголошуючи на тому, що колегіальне самоврядування здатне вести тільки до «вузької корпоративної винятковості», «кумівства», «розвитку особистих інтриг», «створення держави в державі» ${ }^{73}$. Вищезазначене послугувало підставою для визначення таких керівних засад 
реформування університетського устрою: обмеження автономії професорських колегій 3 вилученнях із їх компетенції судової функції; установлення нового порядку призначення професорів; посилення державного контролю за викладанням; обмеження доступу до навчання малопідготовлених і матеріально не забезпечених слухачів.

1875 року була створена спеціальна комісія під керівництвом графа І. Делянова, на яку покладалося завдання щодо підготовки проекту нового університетського статуту. У той же час, з метою поступового переходу до його запровадження вводилася в дію низка циркулярів й інструкцій у вигляді «тимчасових заходів», як-от: «Про тимчасову зміну порядку управління та нагляду за студентами університету», «Тимчасова інструкція для університетської інспекції», нові «Правила для студентів» тощо. Вивчення положень названих документів дає підстави для висновку, що вжиті урядом заходи суттєво обмежували самостійність учених рад Харківського, Київського і Новоросійського університетів, насамперед, у розв'язанні студентських питань. Зокрема, «Тимчасова інструкція...» (1879 р.) змінила пункт 2 ст. 42 статуту, за яким ради самостійно надавали стипендії студентам, а також пункт 9, згідно якого вони володіли правом розпоряджатися спеціальними коштами університету. 31879 року вчені ради втрачали право обирати проректора або інспектора. Надалі ці університетські посадовці передавалися в безпосереднє керівництво попечителя й призначалися ним за погодженням генерал-губернатора.

Вищезазначене дає підстави стверджувати, що в діяльності вчених рад університетів України розпочався новий етап (1884-1901рр.) - етап формалізації діяльності і поглинання їх функцій іншими управлінськими структурами на підставі встановлення жорсткого державного контролю над університетами. Нижня його межа визначається введенням в дію нового університетського статуту 1884 року, а кінець - спробами реформування системи управління університетами Російської імперії, які розпочалися наприкінці XIX - на початку XX століття.

Загальний Статут Імператорських Російських університетів (1884р.), за яким працювали й університети України: Харківський, Київський і Новоросійський, суттєво змінив їх попередній демократичний устрій з автономією й виборчим правом. 3 огляду на це, вчені ради були фактично усунені від безпосереднього управління університетом Так, остаточному затвердженню ради тепер підлягали лише справи, що стосувалися: а) визначення загальної кількості медалей, які присуджувалися студентам і стороннім слухачам за наукові твори; б) їх розподіл між окремими факультетами; в) затвердження наукових ступенів ${ }^{74}$.

Вивчення протоколів засідань учених рад університетів України ${ }^{75}$ дозволяє аргументовано стверджувати: якщо в перші роки після оприлюднення статуту вони ще брали участь в обговоренні проектів окремих правил і заходів, пов'язаних із зміною статей попереднього статуту, то з 1886 року, коли новий порядок остаточно утвердився, їх діяльність обмежувалася виключно «поточними справами», які носили формальний характер ${ }^{76}$. Так, у звітах про діяльність учених рад Харківського, Київського, Новоросійського університетів кінця XIX століття такі справи, як обговорення огляду викладання, використання спеціальних коштів університету, клопотання факультетів про тимчасовий дозвіл на заміщення вакантних кафедр, встановлення розміру винагороди приват-доцентам іменувалися «найважливішими». Але, як правило, ці справи лише заслуховувалися на засіданнях ради й 3 певним висновком передавалися на остаточне вирішення до «вищих інстанцій» ${ }^{77}$. Тому серед рішень учених рад чільне місце посідали такі, що завершувалися формулюванням: «прийняти до відома або виконання».

Фактичне відсторонення вчених рад від управління університетом вимагало перерозподілу їх функцій між іншими управлінськими структурами: попечителем, правлінням, факультетами. Зокрема, за статутом 1884 року значно зросла роль попечителя навчального округу. Він перетворився на «безапеляційно-вирішальну й всеспрямовуючу владу», в руках якої зосереджувалися всі важелі управління, які раніше перебували в компетенції вченої ради. Якщо за статутом 1863 року попечитель міг на власний розсуд втручатися в роботу вченої ради, то згідно статуту 1884 року - був зобов'язаний не лише впливати на неї, а й здійснювати безпосереднє керівництво. Попечитель набував права скликати раду й бути присутнім на іiї засіданнях для роз'яснення найважливіших питань, а також вживати заходів, що стосувалися використання університетських коштів, облаштування навчально-допоміжних установ, вирішення господарських і дисциплінарних справ, покращення 
навчально-виховного процесу тощо. Призначення матеріальної допомоги й стипендій студентам наразі також підлягало владі попечителя, як і те, що він набував права «порушувати справи про відповідальність винних і клопотати про винагороду гідних» ${ }^{78}$.

За статутом 1884 року була значно розширена й влада ректора. Із «першого серед рівних» він перетворився на урядового адміністратора, владі якого мали підкорятися ординарні професори, із середовища яких він призначався міністром терміном на 4 роки. Він оголошувався найближчим помічником попечителя, а відтак виходив 3-під юрисдикції професорської колегії. У разі виникнення надзвичайних обставин, він набував необмеженої влади, навіть якщо рішення з окремих питань перевищували його службові повноваження ${ }^{79}$.

В означений період суттєво зросла дієздатність правління. Окрім фінансових і господарських обов'язків на нього покладалося обрання посадових осіб університетської служби, що раніше належало до компетенції вченої ради. До правління перейшов і розгляд усіх студентських справ, оскільки університетський суд, оголошений «установою малокорисною», був ліквідований. За таких умов учена рада втратила будь-які важелі впливу на студентське середовище і в цьому напрямі діяла цілком відособлено.

Незалежно від ученої ради була поставлена посада інспектора зі студентських справ, який перебував у підпорядкуванні попечителя й ректора. Інспектор визнавався повноправним членом правлінняй набував права голосу під час вирішення будь-яких справ, у тому числі навчальних і наукових ${ }^{80}$.

Значно більшою самостійністю статут 1884 року наділив і факультети, у зв'язку з чим до факультетських зібрань перейшла частина справ, які раніше підлягали розгляду в ученій раді. Так, до справ, які тепер підлягали остаточному вирішенню факультетів, належали: проведення випробувань на вчені ступені, напівкурсових і підсумкових іспитів; надання випускних свідоцтв особам, що закінчили повний курс; прийняття постанов про дозвіл на читання лекцій магістрам у званні приват-доцентів; розгляд наукових творів, рекомендованих для видання за рахунок університету; визначення переліку щорічних завдань студентам і стороннім слухачам для здобуття медалей і премій; обговорення пропозицій ректора щодо покращення університетського викладання; розгляд звітів викладачів про перебіг практичних занять; надання дозволу докторам іноземних університетів на складання іспитів на ступінь магістра тощо. 3 окреслених питань факультети лише інформували вчену раду, а їх рішення передавалися через попечителя на затвердження міністра ${ }^{81}$.

Отже, статут 1884 року фактично анулював самостійність учених рад, відвівши їй роль «виконавчого органу» щодо розпоряджень Міністерства народної освіти й «координуючої інстанції», через яку відбувалися зносини факультетів із попечителем та міністром.

Значних викривлень зазнала й процедура формування особового складу вчених рад, які тепер об'єднували в своїх лавах усіх професорів університету ${ }^{82}$. Позбавлення загальноуніверситетських колегіальних органів права на самопоповнення призвело до того, що «ця справа стала предметом уважного й доброзичливого спостереження міністерства за тим, щоб переваги й недоліки претендентів на професорські посади не залишалися поза увагою, а безвідповідальне ставлення до справи й шкідливі ухили були вчасно знешкоджені ${ }^{83}$. Тобто, під час призначення на посаду професора бралися до уваги, насамперед, благонадійність і спосіб мислення кандидата.

Деякі зрушення в діяльності вчених рад університетів України стали простежуватися лише наприкінці 90-х років XIX століття. Під впливом студентських виступів 1896 року в пресі з'явилася низка публікацій щодо необхідності проведення університетської реформи. Обговорення цього питання розпочалося зі статей С. Трубецького й Б. Чичеріна, надрукованих у «Санкт-Петербурзьких відомостях». Обидва автори вказували, як на головний засіб повернення до спокійного академічного життя, на відновлення університетської автономії, за якої університет буде не «канцелярією», а «об’єднуючим цілим», здатним розумно й морально керувати студентським життям» ${ }^{84}$. Дописувачі підкреслювали, що вчені ради, позбавлені статутом 1884 року права вільно здійснювати керівництво академічним життям, не мають у цьому напрямі ні належного авторитету, ні фактичної можливості для запобігання студентським виступам ${ }^{85}$.

Більш рішуче питання здійснення університетської реформи було поставлене комісією генерал-ад’ютанта П. Вановського 1899 року, яка вперше офіційно визнала, що «в 
самому устрої й внутрішній організації університетів закладено причини, які сприяють виникненню й розповсюдженню безладдя» ${ }^{86} .3$ огляду на це у Височайшому рескрипті від 24 березня 1901 р. на ім'я П. Вановського під час призначення останнього міністром народної освіти імператор вказував на необхідність «терміново розпочати перегляд і виправлення університетського устрою» ${ }^{87}$. На підставі цього рескрипту Міністерство народної освіти ініціювало обговорення змін до чинного статуту 1884 року.

Отже, проведене дослідження дає підстави аргументовано стверджувати, що в організаційно-управлінській структурі університетів України XIX століття вчені ради виступали провідниками принципу автономії й колегіального самоврядування. Проте їх діяльність упродовж окресленого історичного періоду не була сталою й визначалася низкою чинників, як-от: особливості соціально-економічного й політичного розвитку держави, які визначали параметри освітньої політики; розуміння урядовими структурами суті університетської автономії, встановлення ії меж з боку держави, що обумовлювало спектр делегованих загальноуніверситетським колегіальним органам функцій; ступінь розвитку наукового знання, що сприяв підвищенню рівня професійної й управлінської компетентності особового складу вчених рад; чинна система заміщення професорських посад, яка надавала доступ до членства в раді.

${ }^{1}$ Харківський національний університет імені В. Н. Каразіна за 200 років. Харків: Фоліо, 2004.

${ }^{2}$ Георгиевский А. Краткий исторический очерк правительственных мер и предначертаний против студенческих беспорядков. СПб.: Тип. В. С. Балашова, 1890. 302 с.

${ }_{3}^{3}$ Гиляров-Платонов Н. П. Университетский вопрос. СПб.: Изд-во К. Победоносцева, 1903. VIII. $290 \mathrm{c}$.

${ }^{4}$ Головнин А. Н. Мысли об основах реформы высшей школы. М.: Типо-лит. Рихтер, 1906. 36 с.

${ }^{5}$ Рождественский C. В. Очерки по истории систем народного просвещения в России XVIIIXIX веках. СПб.: Тип. Александрова, 1912. Т. 1. 680 с.

${ }^{6}$ Воробьев В. А. К истории наших университетов // Русская мысль. 1905. № 12. С. 1-10.

${ }^{7}$ Иконников В. Русские университеты в связи с ходом общественного образования // Вестник Европы. 1876. № 10. С. 492-549.

${ }^{8}$ Глинский Б. Б. Университетские уставы (1755-1884 гг.) // Исторический вестник. 1900. № 21. C. $325-351$.

${ }^{9}$ Кавелин К. Устройство и управление немецких университетов // Собрание сочинений. СПб. 1899. T. 3. C. 91-239.

${ }_{10}$ Каченовский Д. И. Прежнее и новейшее положение русских университетов // Замечания на проект Общего Устава Императорских российских университетов. Ч. 1. СПб.: Тип. Акад. наук., 1862. C. $345-353$.

${ }^{11}$ Пирогов Н. И. Университетский вопрос. СПб.: [б. и.], 1863. 85 с.

${ }^{12}$ Соловьев И. М. Русские университеты в их уставах и воспоминаниях современников. СПб.: Кн. изд. тип.-литогр. «Энергия», 1914. Вып. 1. 206 с.

${ }^{13}$ Багалій Д. І. Вибрані праці: в 6 т. Т. 3: Опыт истории Харьковского университета (по неизданным материалам). Ч. 1 (1802-1815 гг.). Харків: Вид-во НУА, 2004. 1151 с.; Т. 4: Опыт истории Харьковского университета (по неизданным материалам). Ч. 2 (1815-1835 гг.). Харків: Вид-во НУА, 2005. $1004 \mathrm{c}$.

${ }_{14}^{14}$ Бузескул В. П. История Харьковского университета при действии устава 1884 г. (с 1884 до 1905 г.). Харьков: Тип. ун-та, 1905. 89 с.

${ }_{15}^{15}$ Владимирский-Буданов М. Ф. История Императорского университета Св. Владимира. Т. 1. К.: Тип. ун-та Св. Владимира, 1884. 674 с.

${ }_{16}$ Маркевич А. И. Двадцатипятилетие императорского Новороссийского университета: ист. записка экстраординарного профессора А. И. Маркевича и академические списки. Одесса: Эконом. тип., 1890.734 с.

${ }^{17}$ Сумцов Н. Ф. Материалы для истории Харьковского университета. Харьков, 1894. 23 с.

${ }^{18}$ Шульгин В. История университета Св. Владимира: сочинение Виталия Шульгина, ординарного профессора университета Св. Владимира. СПб.: [б. и], 1860. 230 с.

19 Фортинский Ф. Я. Университет Св. Владимира в царствование Императора Александра III, 1881-1894. К.: Тип. ун-та Св. Владимира. 1900. 35 с.

20 Зайончковский П. Российское самодержавие в конце ХІХ столетия. М.: Мысль, 1970. 444 с.

21 Эймонтова Р. Г. Русские университеты на грани двух эпох. М.: Наука, 1985. 349 с.

${ }^{22}$ Иванов А. Е. Высшая школа России в конце XIX - начале XX в. М.: Наука, 1991. 384 с. 
23 Лейкина-Свирская В. Р. Интеллигенция в России во второй половине XIX века. М.: Мысль, $1971.368 \mathrm{c}$.

${ }^{24}$ Щетинина Г. И. Университеты в России и устав 1884 г. М.: Наука, 1976. 232 с.

${ }^{25}$ Прокопенко Л. Л. Генеза та розвиток державної освітньої політики в Україні (IX - початок ХХ ст.). Монографія. Дніпропетровськ: ДРІДУ НАДУ, 2008. С. 184.

${ }^{26}$ Харківський національний університет імені В. Н. Каразіна за 200 років. С. 36-39.

${ }^{27}$ Там само.

${ }^{28}$ Колесников И. В., Круглов Ю. Г., Олесеюк Е. В. Формирование системы управления университетами в России // Педагогика. 2003. № 2. С. 51.

${ }^{29}$ Университетская идея в Российской империи XVIII - начала XX веков. Антология: учеб. пособие для вузов / Сост.: А. Ю. Андреев, С. И. Посохов. М.: РОССПЭН, 2011. 527 с.

${ }^{30}$ Харківський національний університет імені В. Н. Каразіна за 200 років. С. 228.

${ }^{31}$ Иконников В. Русские университеты в связи с ходом общественного образования. С. 535.

32 Кравченко В. Університет для України // Схід-Захід: іст.-культуролог. зб. Харків-Київ, 2005. Вип. 7. С. 147.

33 Устав Императорского Харьковского университета 1804 г. // Периодические сочинения об успехах народного просвещения. 1805. № 10. С. 225-285.

${ }_{34}^{34}$ Багалій Д. І. Вибрані праці: в 6 т. Т. 3. Ч. 1.

${ }^{35}$ Устав Императорского Харьковского университета 1804 г. С. 241-248.

${ }^{36}$ Багалій Д. І. Вибрані праці: в 6 т. Т. 3. Ч. 1.

${ }^{37}$ Там само. С. 272.

38 Устав Императорского Харьковского университета 1804 г. С. 240.

${ }^{39}$ Багалій Д. І. Вибрані праці: в 6 т. Т. 3. Ч. 1. С. 272.

${ }^{40}$ Багалій Д. І. Вибрані праці: в 6 т. Т. 3. Ч. 1; Иконников В. Русские университеты в связи с ходом общественного образования.

${ }^{41}$ Устав Императорского Харьковского университета 1804 г. С. 240.

42 Яновський Л. Харківський університет на початку свого існування (1805-1820). Харків: Майдан, 2004. С. 157-158.

${ }_{43}$ Андреев А. Ю., Феофанов А. М. Иностранные профессора российских университетов (вторая половина XVIII - первая треть XIX в.): Биографический словарь. М.: РОССПЭН, 2011. 207 с.

${ }_{44}^{44}$ Багалій Д. І. Вибрані праці: в 6 т. Т. 4. Ч. 2. С. 70.

${ }^{45}$ Багалій Д. І. Вибрані праці: в 6 т. Т. 4. Ч. 2.; Харківський національний університет імені В. Н. Каразіна за 200 років; Кравченко В. Університет для України.

${ }^{46}$ Рождественский С. В. Исторический обзор деятельности Министерства народного просвещения (1802-1902). СПб., 1902. 776 с.

${ }^{47}$ Там само. С. 191.

${ }^{48}$ Там само.

${ }^{49}$ Там само. С. 243.

${ }^{50}$ Там само. $50 \mathrm{c}$.

${ }^{51}$ Общий устав Императорских российских университетов 1835 г. Харьков: Тип. ун-та, 1837.

52 Краткий очерк истории Харьковского университета за первые сто лет его существования (1805-1905), составленный профессорами Д. И. Багалеем, Н. Ф. Сумцовым, В. П. Бузескулом. Харьков: Тип. А. Дарре, 1906. С. 119.

${ }_{53}$ Там само. С. 116.

${ }_{55}^{54}$ Общий устав Императорских российских университетов 1835 г. С. 13.

${ }_{55}^{5}$ Глинский Б. Б. Университетские уставы (1755-1884 гг). С. 342.

${ }_{56}^{5}$ Краткий очерк истории Харьковского университета за первые сто лет его существования. C. 119.

${ }^{57}$ Владимирский-Буданов М. Ф. История Императорского университета Св. Владимира. С. 70.

${ }^{58}$ Общий устав Императорских российских университетов 1835 г. С. 10-12.

${ }^{59}$ Центральний державний історичний архів України, м. Київ. Ф. 707. Оп. 17. Спр. 70. 22 арк.

${ }^{60}$ Глинский Б. Б. Университетские уставы (1755-1884 гг). С. 351.

${ }^{61}$ Посохов С. І. Образи університетів Російської імперії другої половини XIX - початку XX ст. в публіцистиці та історіографії. Харків: ХНУ імені В. Н. Каразіна, 2006. С. 56.

${ }_{62}$ Общий устав Императорских российских университетов 1863 г. СПб., 1863. С. 15-17.

${ }^{63}$ Там само. С. $17-18$.

${ }^{64}$ Протокол заседания Совета университета Св. Владимира, 10-го августа 1863 г.// Университетские известия. 1863. № 1-9. С. 1-23.

65 Протоколы заседаний Совета Императорского Харьковского университета и приложения к ним. Х., 1863. № 1-6.94 с.

${ }^{66}$ Протоколы заседаний Совета Императорского университета Св. Владимира, 7-го, 22-го и 29-го сентября 1878 года // Университетские известия. 1878. № 12. С. 1-77. 
${ }^{67}$ Общий устав Императорских российских университетов 1863 г. СПб., 1863. С. 18.

${ }^{68}$ Краткий очерк истории Харьковского университета запервые сто лет его существования...С. 173.

69 Протоколы заседаний Совета Императорского Харьковского университета и приложения к ним. 1863. № 1-6. С. 3-4. C. 180 .

${ }^{70}$ Краткий очерк истории Харьковского университета за первые сто лет его существования...

${ }^{71}$ Харківський національний університет імені В. Н. Каразіна за 200 років. С. 133.

${ }^{72}$ Искра Л. М. Б. Н. Чичерин и университетская реформа 1884 г. // Российские университеты в XIX начале XX века. Воронеж, 1993. С. 93.

${ }^{73}$ Посохов С. I. Образи університетів Російської імперії другої половини XIX - початку XX ст. в публіцистиці та історіографії. С. 58-60.

${ }_{74}$ Общий устав Императорских российских университетов 1884 г. СПб., 1884. С. 16-17.

75 Протоколы заседаний Совета Императорского Новороссийского университета с 19-го апреля по 20-е августа 1884 года // Записки Императорского Новороссийского университета. Одесса. 1885. T. 41. C. 107-180.

${ }^{76}$ Протоколы заседаний Совета университета Св. Владимира 23-го марта и 31-го мая 1890 года // Университетские известия. 1890. № 11. С. 55-75; Державний архів Одеської області. Ф. 45. Оп. 8. Спр. 5, 1896. 104 арк.

77 Бузескул В. П. История Харьковского университета при действии устава 1884 г. (с 1884 до 1905 г.). Харьков: Тип. ун-та, 1905. С. 16.

${ }^{78}$ Общий устав Императорских российских университетов 1884 г. С. 9-10.

79 Там само. C. 10-12.

${ }^{80}$ Бузекул В. П. История Харьковского университета при действии устава 1884 г. (с 1884 до 1905 г.). С. 5.

${ }^{81}$ Общий устав Императорских российских университетов 1884 г. С. 12-16.

${ }^{82}$ Там само. C. 16

${ }^{83}$ Бузекул В. П. История Харьковского университета при действии устава 1884 г. (с 1884 до 1905 г.). С. 7.

84 Университет // Энциклопедическийсловарь / Изд. Ф. А. Брокгауз, И. А. Ефрон. СПб., 1902. T. 34A. C. 797.

${ }^{85}$ Воробъев В. А. К истории наших университетов. С. 9.

${ }^{86}$ Университет // Энциклопедический словарь.Т. 34А. С. 797.

87 Бузекул В. П. История Харьковского университета при действии устава 1884 г. (с 1884 до 1905 г.). С. 19. 